\title{
Estimating Logged-Over Lowland Rainforest Aboveground Biomass in Sabah, Malaysia Using Airborne LiDAR Data
}

\author{
Mui-How Phua ${ }^{1, *}$, Su Wah Hue ${ }^{1}$, Keiko Ioki ${ }^{1}$, Mazlan Hashim ${ }^{2}$, Kawi Bidin' $^{1}$, Baba Musta ${ }^{1}$, \\ Monica Suleiman ${ }^{3}$, Sau Wai Yap ${ }^{4}$, and Colin R. Maycock ${ }^{1}$ \\ ${ }^{1}$ Faculty of Science and Natural Resources, Universiti Malaysia Sabah, Sabah, Malaysia \\ ${ }^{2}$ Institute of Geospatial Science and Technology, Universiti Teknologi Malaysia, Johor, Malaysia \\ ${ }^{3}$ Institute of Tropical Biology and Conservation, Universiti Malaysia Sabah, Sabah, Malaysia \\ ${ }^{4}$ Conservation \& Environmental Management Division, Yayasan Sabah Group, Kota Kinabalu, Sabah, Malaysia
}

Received 2 June 2015, revised 25 December 2015, accepted 6 January 2016

\begin{abstract}
Unprecedented deforestation and forest degradation in recent decades have severely depleted the carbon storage in Borneo. Estimating aboveground biomass (AGB) with high accuracy is crucial to quantifying carbon stocks for Reducing Emissions from Deforestation and Forest Degradation-plus implementation (REDD+). Airborne Light Detection and Ranging (LiDAR) is a promising remote sensing technology that provides fine-scale forest structure variability data. This paper highlights the use of airborne LiDAR data for estimating the AGB of a logged-over tropical forest in Sabah, Malaysia. The LiDAR data was acquired using an Optech Orion C200 sensor onboard a fixed wing aircraft. The canopy height of each LiDAR point was calculated from the height difference between the first returns and the Digital Terrain Model (DTM) constructed from the ground points. Among the obtained LiDAR height metrics, the mean canopy height produced the strongest relationship

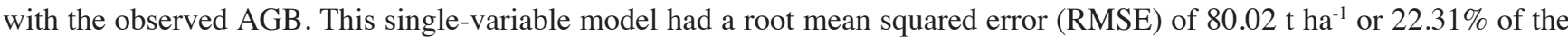
mean AGB, which performed exceptionally when compared with recent tropical rainforest studies. Overall, airborne LiDAR did provide fine-scale canopy height measurements for accurately and reliably estimating the AGB in a logged-over forest in Sabah, thus supporting the state's effort in realizing the REDD+ mechanism.
\end{abstract}

Key words: Aboveground biomass, Selective logging, LiDAR, Sabah

Citation: Phua, M. H., S. W. Hue, K. Ioki, M. Hashim, K. Bidin, B. Musta, M. Suleiman, S. W. Yap, and C. R. Maycock, 2016: Estimating loggedover lowland rainforest aboveground biomass in Sabah, Malaysia using airborne LiDAR data. Terr. Atmos. Ocean. Sci., 27, 481-489, doi: 10.3319/ TAO.2016.01.06.02(ISRS)

\section{INTRODUCTION}

Over past decades the lowland rainforest of Borneo has disappeared at an alarming rate due to anthropogenic activities, with recent rates of deforestation at $1.7 \%$ per year between 2002 and 2005 (Langner et al. 2007). The land area of Sabah is $73631 \mathrm{~km}^{2}$, representing slightly less than $10 \%$ of the total area of Borneo. Within Sabah, forest cover has declined rapidly from nearly $75 \%$ in 1975 (Ross 2001), to $60.1 \%$ in 1986 (FAO 1987). The rates of forest loss have varied over this time, with forest loss estimates of $1.37 \%$ per year for the period $1975-1985$. The deforestation rate between 1990 and 2008 had recently increased to $1.6 \%$ per year (Osman et al. 2012). This sharp decline in primary or

\footnotetext{
* Corresponding author

E-mail:pmh@ums.edu.my
}

intact lowland forests in Sabah was due mainly to forestagricultural land conversion and logging (McMorrow and Talip 2001; Osman et al. 2012) that accelerated carbon depletion. This leads to increasing carbon emissions into the atmosphere and thus contributes to global warming.

Reducing Emissions from Deforestation and forest Degradation (REDD) has been under negotiation by the United Nations Framework Convention on Climate Change (UNFCCC) to mitigate global warming since 2005. This scheme was later known as REDD+ after putting an emphasis on the roles of conservation, sustainable forest management and forest carbon stock activities enhancement as a mitigation strategy against the increasing carbon emissions due to land use and land cover change (UNFCCC 2009). Accurate carbon stock estimation and monitoring is 
important to REDD+ success. In order to implement REDD+ effectively it is recommended that remote sensing technology be applied with ground inventory (UNFCCC 2009). Ground inventory can be expensive and time consuming to produce consistent global data (Chave et al. 2005), hence it is necessary to apply remote sensing technology to assess forest condition information in large inaccessible areas (Saatchi et al. 2007).

Remote sensing technology, especially optical satellite imaging, has been widely used in aboveground biomass (AGB) estimation based on multispectral (Phua and Saito 2003; Langner et al. 2012) and texture information (Lu 2005). Conventionally, the spectral responses of the vegetation cover are related with estimated AGB through a statistical model (Brown 1997). Unfortunately, cloud cover, the shadow effect and low spectral band saturation level and derived indices (Gibbs et al. 2007) limits the application of medium resolution satellite remote sensing for AGB estimation. Additional information such as crown variables extracted from high-resolution satellite remote sensing improves the AGB estimation results (Palace et al. 2008; Phua et al. 2014). However, optical satellite remote sensing provides information only on the upper canopy trees and may substantially underestimate the AGB of a disturbed forest (Lu 2005, 2006). Anthropogenic disturbances, especially logging, create complex three-dimensional structures, including canopy height and sub-canopy topography, which are less likely to be detected by optical satellite remote sensing (Ioki et al. 2014).

Light Detection and Ranging (LiDAR) has the potential to overcome these problems. LiDAR is an active remote sensing that emits laser pulses to the target area and records the travel time of the reflected pulse. The emitted lasers fall on the canopy surface and also penetrate the forest canopy to assess the dense and complex forest structure. The reflected laser pulses generate three dimensional point clouds $(\mathrm{x}, \mathrm{y}, \mathrm{z})$ to give a direct measurement of the horizontal and vertical forest structures (Wulder et al. 2012).

Numerous studies have highlighted the importance of airborne LiDAR in estimating AGB in temperate and boreal forests but only a few studies focused on tropical forests. Clark et al. (2011) demonstrates the effectiveness of small footprint LiDAR for AGB estimation in Costa Rica by deriving LiDAR height metrics to estimate the forest AGB. Asner et al. (2012c) examined the effectiveness of the extracted mean canopy height to estimate AGB in Panama, Peru, Madagascar, and Hawaii $\left(R^{2}=0.8, \mathrm{RMSE}=27.6 \mathrm{MgCha}^{-1}\right)$. In Borneo, Kronseder et al. (2012) and Jubanski et al. (2013) examined the use of LiDAR derived height metrics to estimate the AGB in logged peat swamp forest and unlogged lowland dipterocarp forest in Central Kalimantan. Ioki et al. (2014) tested the use of laser penetration rate from LiDAR data for AGB estimation of primary and degraded tropical montane forests of in Sabah, Borneo $\left(R^{2}=0.78\right.$, RMSE $=$ $\left.27.6 \mathrm{t} \mathrm{ha}^{-1}\right)$.

Most of the lowland dipterocarps in Borneo were repeatedly logged and disturbed by anthropogenic activities. These logged-over forests have a highly heterogeneous forest structure. A disturbed forest recovers by undergoing growth in horizontal (e.g., diameter at breast height, DBH) and vertical structure (e.g., stand height) accompanied with the overall increase in AGB. Horizontal and vertical structures are inter-related with AGB, thus creating an opportunity for LiDAR to examine the forest in different structural conditions (Lefsky et al. 1999, 2002; Drake et al. 2002). High point density and multiple discrete heights from small footprint airborne LiDAR can retrieve such forest structures and predict AGB in fine spatial scale (Houghton 2005). Studies on the use of LiDAR to estimate logged-over lowland dipterocarp forests are relatively few. The objective of this study is to examine the use of airborne LiDAR data to estimate AGB in a logged-over lowland dipterocarp forest in Sabah, Malaysia.

\section{MATERIAL AND METHODS}

\subsection{Study Area}

The study area is located within the Sapat Kalisun catchment within the Ulu Segama Forest Reserve $\left(5^{\circ} \mathrm{N}\right.$; $\left.117^{\circ} 30^{\prime} \mathrm{E}\right)$ under the management of Yayasan Sabah (Fig. 1). It is located just outside Danum Valley Field Center (DVFC), which is about $70 \mathrm{~km}$ west of Lahad Datu town. The forest in this region is dipterocarp forest, with Parashorea malaanonam as the typical dominant tree species. The dipterocarp forest of Sapat Kalisun is dominated by species from Dipterocarpaceae and Euphorbiaceae while the understory is dominated by Rubiaceae and Melastomataceae families (Newbery et al. 1992).

The Sapat Kalisun catchment is generally undulating to hilly but not mountainous. This study site was selectively logged in 1988 and 1989, with an annual production volume of between $96-100 \mathrm{~m}^{3} \mathrm{ha}^{-1}$ (Tangki and Chappell 2008). The logging operation was conducted using a combination of tractor and high lead logging. After logging, the coupes were closed down and the study site was allowed to regenerate naturally.

\subsection{Acquisition and Processing of Airborne LiDAR Data}

Airborne LiDAR data were acquired in October 2013 using an Optech C200 sensor, mounted on a Nomad C22 aircraft. The LiDAR data collection mission was operated at an altitude of $600 \mathrm{~m}$, speed of $41.2 \mathrm{~m} \mathrm{~s}^{-1}$, scan angle of $\pm 14^{\circ}$ and pulse frequency of $175 \mathrm{kHz}$ (Table 1). The sensor system also consists of a differential global navigation satellite system (DGNSS) receiver coupled to an inertial measurement unit, both components ensuring that a sub-decimeter 
differential position can be calculated for the aircraft in postprocessing. A calibration site within a residential area (less than $20 \mathrm{~km}$ ) was also scanned for LiDAR data processing.

We used the Applanix IN-Fusion ${ }^{\mathrm{TM}}$ single baseline processing approach to generate the optimal smoothed best estimate of trajectory (SBET) from the global navigation satellite system (GNSS) and inertial data in POSPac Mobile Mapping Suite (MMS). This approach requires the rover to be at most $70 \mathrm{~km}$ from the nearest reference station to initially resolve the correct ambiguities (Hutton et al. 2008). We established the reference station with Javad Triumph-1 on a surveying benchmark at Taliwas Forest Reserve during the LiDAR data acquisition. The GNSS base station data was post-processed with Javad's proprietary software (Justin). The generated SBET was used to calibrate the raw LiDAR range data in Optech's LiDAR Mapping Suit (LMS) software to calculate the boresight misalignments $(\mathrm{x}, \mathrm{y}, \mathrm{z})$ for the calibration site. The boresight misalignments were estimated in LMS with iterative pitch shift, roll shift, mirror scale, and heading shift error calculations. The laser point clouds in las 1.2 format were extracted for further processing in Microstation V8i. Points that were obviously much higher than the surrounding points were removed as noise. The average point density of the point cloud was 25 points $\mathrm{m}^{-2}$.

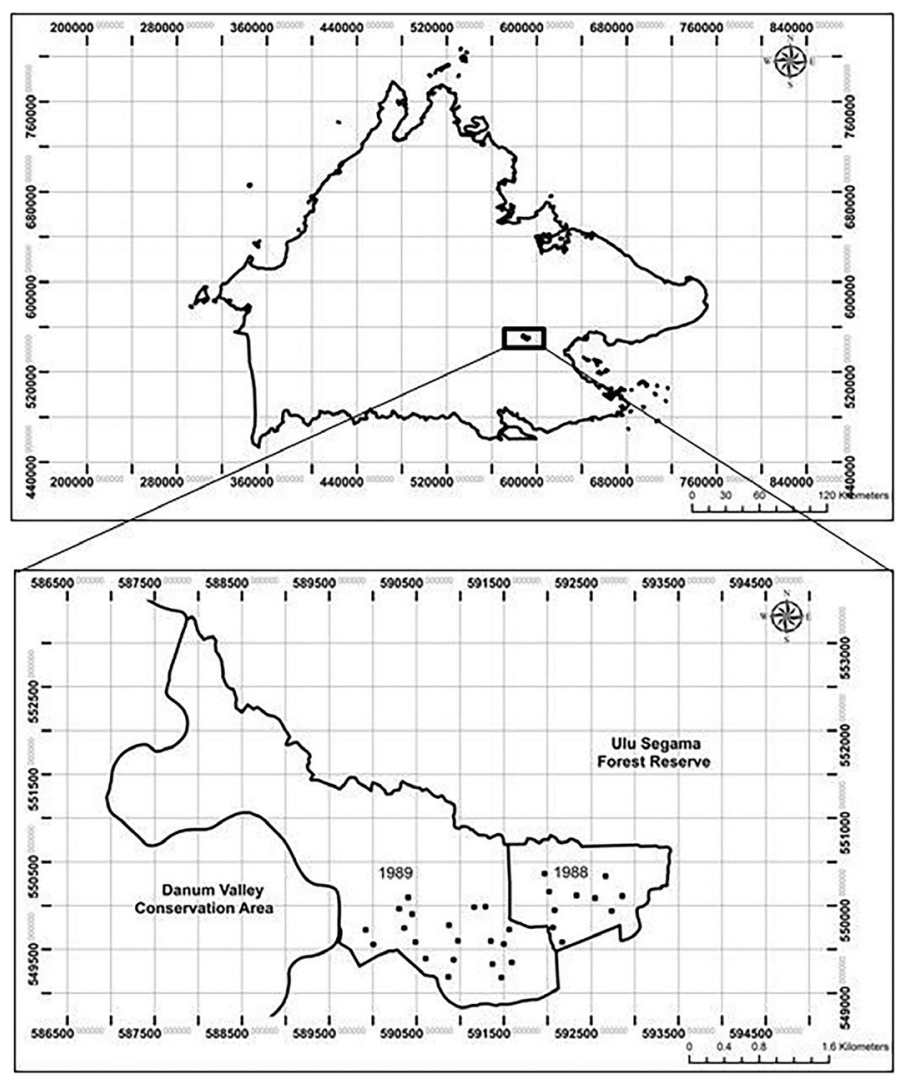

Fig. 1. Location of the study area. The study site comprised of logging coupes of 1988 and 1989 (plots in black color squres) in the Ulu Segama Forest Reserve, which is next to Danum Valley Conservation Area. Box in dashed line is LiDAR scanning area.

Table 1. Summary of LiDAR data acquisition using Optech C200 system.

\begin{tabular}{cc}
\hline System & Optech C200 \\
\hline Date of acquisition & 11 October 2013 \\
Platform & airplane (Nomad N22) \\
Flying altitude & about $600 \mathrm{~m}$ above ground $^{-1}$ \\
Average speed & $41.2 \mathrm{~m} \mathrm{~s}^{-1}$ \\
Scan angle & $\pm 14^{\circ}$ \\
Scanning frequency & $70 \mathrm{~Hz}$ \\
\hline
\end{tabular}


We then used a filtering algorithm (Axelsson 2000) in TerraScan software to process and classify point clouds into ground and vegetation points. The ground points were distinguished by iteratively building a triangulated surface model with the following parameters: maximum building size $=60 \mathrm{~m}$, terrain angle $=88^{\circ}$, iteration angle $=6^{\circ}$, and iteration distance $=1.4 \mathrm{~m}$. The ground points were used to correct the pitch shift, roll shift, mirror scale, heading shift, and then $\mathrm{z}$ shift in TerraMatch. The overall elevation bias for the flight lines was $0.1044 \mathrm{~m}$.

The terrain points were used to generate a Digital Terrain Model (DTM) (pixel size $1 \mathrm{~m}$ ) with the triangulation method in ArcGIS. Figure 2 shows examples of the vegetation point cloud profiles (first returns) from plots. The canopy height was calculated by taking the height difference between the first returns and the DTM. Canopy height point clouds were clipped using plot boundary polygons. We then calculated LiDAR variables, including maximum $\left(\mathrm{h}_{\max }\right)$ and mean $\left(\mathrm{h}_{\text {mean }}\right)$ canopy height as well as the $10^{\text {th }}, 30^{\text {th }}, 50^{\text {th }}, 70^{\text {th }}$, and $90^{\text {th }}$ percentiles $\left(h_{10}, h_{30}, h_{50}, h_{70}, h_{90}\right)$ of canopy height, from the point clouds for all the plots.

\subsection{Forest Inventory}

The field data were collected in April, June, and October 2014 . Thirty square plots $(30 \times 30 \mathrm{~m})$ were randomly established within the study site to estimate AGB. All trees in the plot with DBH greater than $10 \mathrm{~cm}$ were measured. The structural variables included $\mathrm{DBH}$, tree height $(\mathrm{H})$ and crown diameter. Tree species were identified in the field by an experienced and field-botanist. Specimens were collected for species that could not be identified in the field for further determination at the DVFC herbarium.

The plot locations were determined using the Javad Triumph-1 receivers. We first established a base station at the DVFC weather station by referring to the nearest surveying benchmark at Taliwas Forest Reserve using the differential positioning method (static survey). A GNSS receiver was established at the base station while a rover was placed at the center of each plot to determine the plot's location at centimeter accuracy. The two DGNSS receivers received signals from the Global Orbiting Navigation Satellite System (GLONASS) and Global Positioning System (GPS) concurrently to allow GNSS data post-processing to correct the positioning error based on the difference between the signal ranges of these two points.

AGB for each tree was calculated from the DBH and height $(\mathrm{H})$ data using an existing allometric equation (Yamakura et al. 1986). This allometric equation was developed in an undisturbed lowland dipterocarp forest at East Kalimantan, Indonesia. In the allometric equation AGB as dry weight $(\mathrm{kg})$ of a single tree is calculated by summing up various tree components i.e., $\mathrm{w}_{\mathrm{S}}$ (stem dry weight), $\mathrm{w}_{\mathrm{B}}$ (branch dry weight), and $\mathrm{w}_{\mathrm{L}}$ (leaf dry weight), calculated (a)
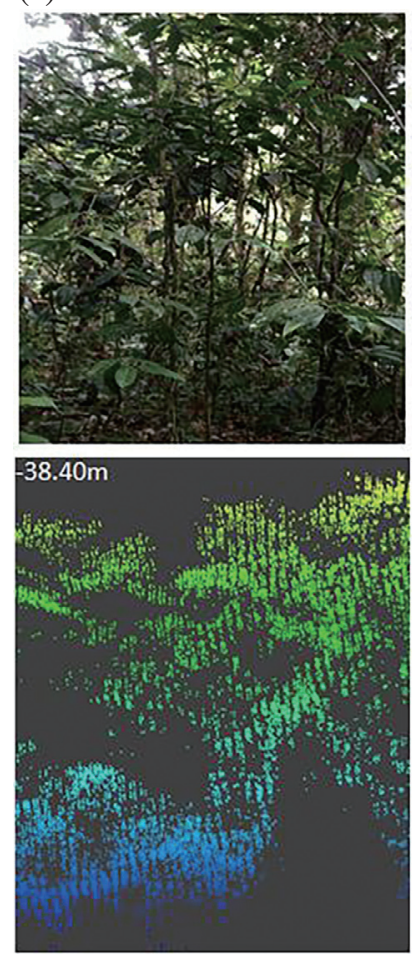

(b)
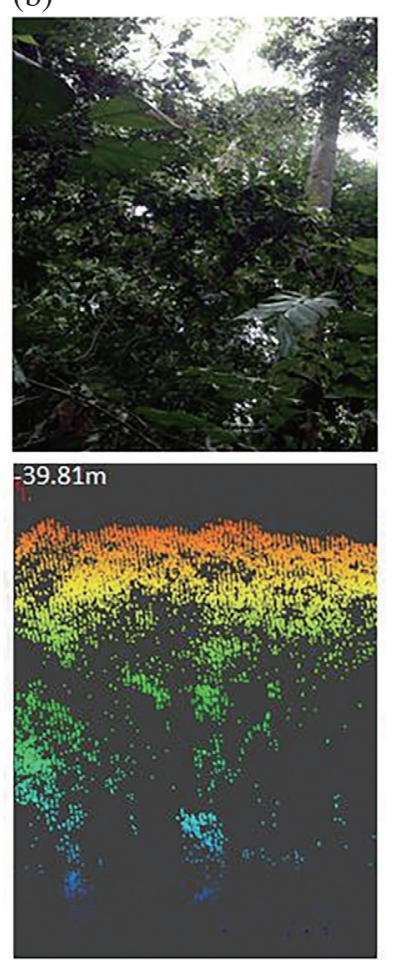

(c)
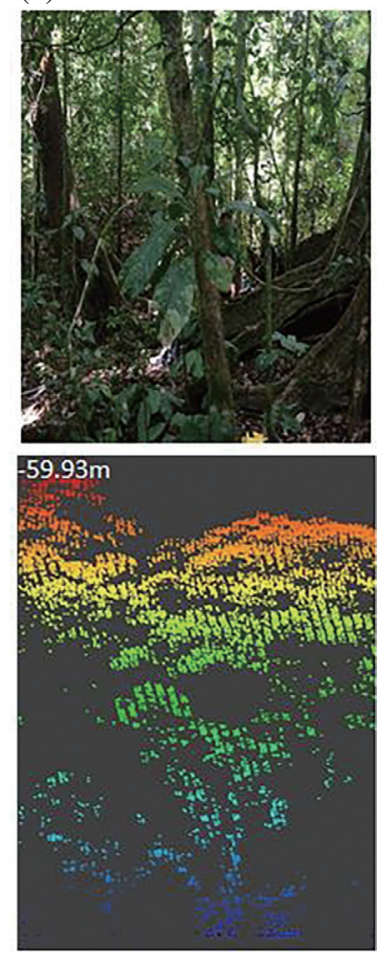

Fig. 2. The LiDAR point clouds of selected plots. (a) Plot DV20 (maximum canopy height: $38.4 \mathrm{~m}$, AGB: 215.54 t ha-1); (b) Plot DV05 (maximum canopy height: $39.81 \mathrm{~m}$, AGB: $316.31 \mathrm{t} \mathrm{ha}^{-1}$ ); (c) Plot DV305 (maximum canopy height: $59.93 \mathrm{~m}$, AGB: $757.56 \mathrm{t} \mathrm{ha}^{-1}$ ). (Color online only) 
using the following equations;

$\mathrm{w}_{\mathrm{S}}=2.906 \times 10^{-2}\left(\mathrm{DBH}^{2} \mathrm{H}\right)^{0.9813}$

$\mathrm{W}_{\mathrm{B}}=0.1192 \mathrm{w}_{\mathrm{S}}^{1.059}$

$\mathrm{W}_{\mathrm{L}}=9.146 \times 10^{-2}\left(\mathrm{w}_{\mathrm{S}}+\mathrm{w}_{\mathrm{B}}\right)^{0.7266}$

$\mathrm{AGB}=\mathrm{w}_{\mathrm{S}}+\mathrm{w}_{\mathrm{B}}+\mathrm{w}_{\mathrm{L}}$

The AGB $(\mathrm{kg})$ for all trees within the plot were summed and used to calculate the plot level AGB in $\mathrm{tha}^{-1}$.

\subsection{Statistical Analyses}

One of the most common LiDAR approaches for AGB estimation was used in this study (Magnussen and Boudewyn 1998; Patenaude et al. 2004; Kronseder et al. 2012; Ioki et al. 2014). LiDAR variables calculated from the point clouds within the plots were regressed with field measurements. The LiDAR variables, including mean canopy height $\left(\mathrm{h}_{\text {mean }}\right)$, maximum canopy profile height $\left(\mathrm{h}_{\max }\right)$, percentiles of canopy height corresponding to $10^{\text {th }}, 30^{\text {th }}, 50^{\text {th }}, 70^{\text {th }}$, and $90^{\text {th }}$ $\left(\mathrm{h}_{10}, \mathrm{~h}_{30}, \mathrm{~h}_{50}, \mathrm{~h}_{70}, \mathrm{~h}_{90}\right)$, were used as predictors in plot level AGB statistical analysis.

We first performed correlation analysis to explore the statistical association between the LiDAR variables and AGB. This was followed by simple regression analysis to examine the performance of the each variable in AGB estimation. Multiple linear regression analysis was then performed to examine any further model improvement by incorporating multiple LiDAR variables. The simple regression analyses were carried out with power models because the power models were successfully used to estimate AGB in tropical forests (Asner et al. 2012a, b; Jubanski et al. 2013). In the multiple regression analysis all LiDAR variables were transformed using the natural logarithm and stepwise regression using the Akaike Information Criterion (AIC) conducted to determine the final model. The independent variables with the lowest AIC value will be included in the final model. Coefficient of determination $\left(R^{2}\right)$, the root mean squared error (RMSE) and RMSE as a percentage of the average AGB (RMSE \%) were used for model evaluation. Leave-one-out cross-validation (LOOCV) was carried out for testing the overfitting of the final model using R software (http://cran.r-project.org/). One plot was selected as a validation sample while the remaining $\mathrm{N}-1$ plots were used to train the model. The predictive value was assessed by comparing the cross-validated RMSE (RMSEcv) with the full model RMSE. A close agreement between the RMSEcv and RMSE indicates that the model is not overfitting the data and the predictive value is good.

\section{RESULTS}

\subsection{Forest Structure and AGB of the Logged-Over Forest}

Field measurements of the main structural variables i.e., DBH and $\mathrm{H}$ were examined to understand the logged- over forest characteristics. The mean DBH was $22.45 \mathrm{~cm}$ with a maximum of $135 \mathrm{~cm}$. Tree height ranged between $4.1-65 \mathrm{~m}$, with a mean of $18.5 \mathrm{~m}$ (Table 2). Tree height was strongly correlated to DBH with an $R^{2}$ of 0.74 (Fig. 3). There were only six trees greater than $50 \mathrm{~m}$ tall in the study areas. The estimated AGB ranged from 170.64 - $757.66 \mathrm{t} \mathrm{ha}^{-1}$, with a mean $( \pm \mathrm{SD})$ of $358.58 \mathrm{t} \mathrm{ha}^{-1}( \pm 132.79)$, with trees between 20 - $50 \mathrm{~m}$ tall contributed the bulk of the AGB of the loggedover forest (Fig. 4).

Table 2. Summary of field measurements on the forest structure.

\begin{tabular}{lcccc}
\hline & Mean & SD & Min & Max \\
\hline DBH $(\mathrm{cm})$ & 22.45 & 16.65 & 10 & 135 \\
Height $(\mathrm{m})$ & 18.49 & 8.61 & 4.1 & 65 \\
AGB $\left(\mathrm{t} \mathrm{ha}^{-1}\right)$ & 358.58 & 132.79 & 170.64 & 757.66 \\
\hline
\end{tabular}

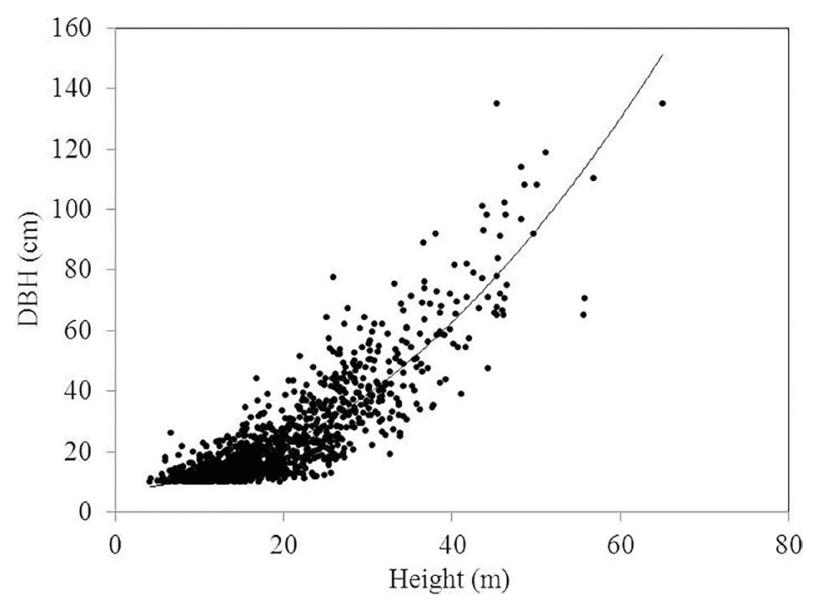

Fig. 3. Relationship between $\mathrm{H}(\mathrm{m})$ and $\mathrm{DBH}(\mathrm{cm})$ in the logged-over forest. Very few large trees were present due to past selective logging.

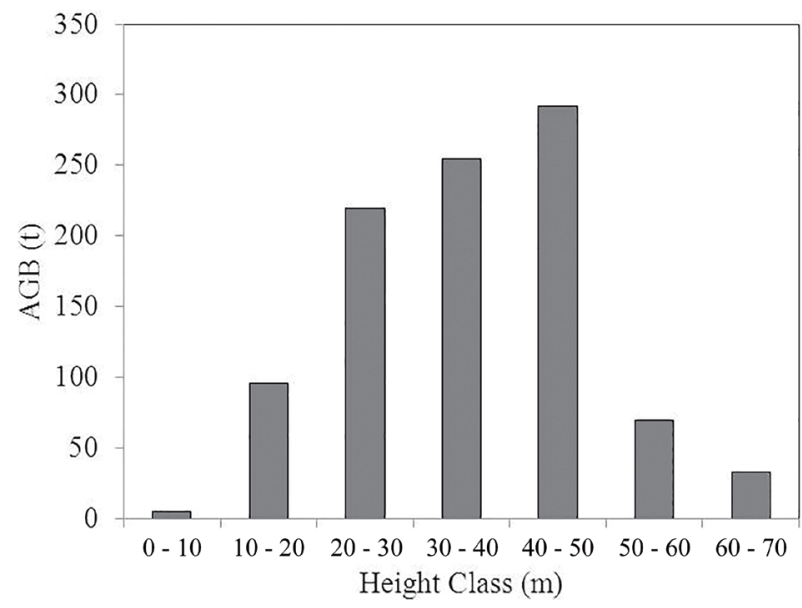

Fig. 4. AGB ( $\mathrm{t}$ ) distribution in height classes $(\mathrm{m})$ based on field data. 


\subsection{AGB Estimation Model}

Table 3 shows the correlations between AGB $\left(\mathrm{t} \mathrm{ha}^{-1}\right)$ with different LiDAR variables estimated for the 30 plots. With a coefficient $R$ (Pearson correlation) of $0.80, \mathrm{~h}_{\text {mean }}$ having the strongest correlation with AGB in the logged-over forest. This was followed by the $50^{\text {th }}$ percentile or median of canopy height with a coefficient $R$ of 0.75 . Only $\mathrm{h}_{\max }$ had no significant correlation with AGB. The correlations decreased with lower and also higher percentile variables.

Simple regression with power models to estimate AGB were tested with all the LiDAR variables. The results indicate that $\mathrm{h}_{\text {mean }}$ was the best predictor of AGB compared to all other LiDAR variables (Table 3 ). The power model fitted to the plot data had a $R^{2}$ of 0.67 (sig. 0.01) (Fig. 5). In the stepwise multiple regression analysis, only $\mathrm{h}_{\text {mean }}$ was retained in the final model. The $\mathrm{h}_{\text {mean }}$ had the lowest AIC value in

Table 3. Correlation and simple regression analyses between AGB and LiDAR variables.

\begin{tabular}{ccccc}
\hline Variables & $\boldsymbol{R}$ & $\boldsymbol{R}^{2}$ (power model) & RMSE $\left(\mathbf{t} \mathbf{h a}^{-1}\right.$ ) & RMSE $(\boldsymbol{\%})$ \\
\hline $\mathrm{h}_{10}$ & $0.50^{*}$ & $0.27^{*}$ & 115.95 & 32.34 \\
$\mathrm{~h}_{30}$ & $0.62^{* *}$ & $0.37^{* *}$ & 106.27 & 29.64 \\
$\mathrm{~h}_{50}$ & $0.75^{* *}$ & 0.58 & 88.40 & 24.65 \\
$\mathrm{~h}_{70}$ & $0.66^{* *}$ & $0.48^{* *}$ & 101.16 & 28.21 \\
$\mathrm{~h}_{90}$ & $0.59^{* *}$ & $0.39^{* *}$ & 107.85 & 30.08 \\
$\mathrm{~h}_{\text {max }}$ & 0.39 & 0.13 & 123.94 & 34.56 \\
$\mathrm{~h}_{\text {mean }}$ & $0.80^{* *}$ & $0.67 * *$ & 80.02 & 22.31 \\
\hline
\end{tabular}

Note: *: significant at the 0.05 level; **: significant at the 0.01 level.

Table 4. Multiple linear regression analyses results using Akaike Information Criterion (AIC).

\begin{tabular}{cc}
\hline Variables included in the model & AIC \\
\hline $\mathrm{h}_{50}, \mathrm{~h}_{90}, \mathrm{~h}_{30}, \mathrm{~h}_{70}, \mathrm{~h}_{10}, \mathrm{~h}_{\text {mean }}$ & 272.62 \\
$\mathrm{~h}_{90}, \mathrm{~h}_{30}, \mathrm{~h}_{70}, \mathrm{~h}_{10}, \mathrm{~h}_{\text {mean }}$ & 271.35 \\
$\mathrm{~h}_{30}, \mathrm{~h}_{70}, \mathrm{~h}_{10}, \mathrm{~h}_{\text {mean }}$ & 269.67 \\
$\mathrm{~h}_{70}, \mathrm{~h}_{10}, \mathrm{~h}_{\text {mean }}$ & 268.07 \\
$\mathrm{~h}_{10}, \mathrm{~h}_{\text {mean }}$ & 267.77 \\
$\mathrm{~h}_{\text {mean }}$ & 266.29 \\
\hline
\end{tabular}

comparison to other multiple variable models (Table 4). The multiple regression analysis did confirm that the simple regression model with $\mathrm{h}_{\text {mean }}$ as the predictor is the best model to estimate the AGB for this forest. The full model RMSE was $80.02 \mathrm{t} \mathrm{ha}^{-1}$ or $22.31 \%$ of the average AGB. The RMSEcv calculated using LOOCV was $87.40 \mathrm{t} \mathrm{ha}^{-1}$ or $24.37 \%$. The difference between the RMSE and the RMSEcv was $7.38 \mathrm{t} \mathrm{ha}^{-1}$ or about $2 \%$ relative to the mean AGB. A scatterplot of the observed AGB versus the LiDAR estimated AGB is shown in Fig. 6. The regression line was well-fitted between the observed AGB and LiDAR estimated AGB through the origin with a slope of 0.94 .

\section{DISCUSSION}

Most of the lowland rainforest in Sabah had been logged at least once starting from the 1960s. The study site

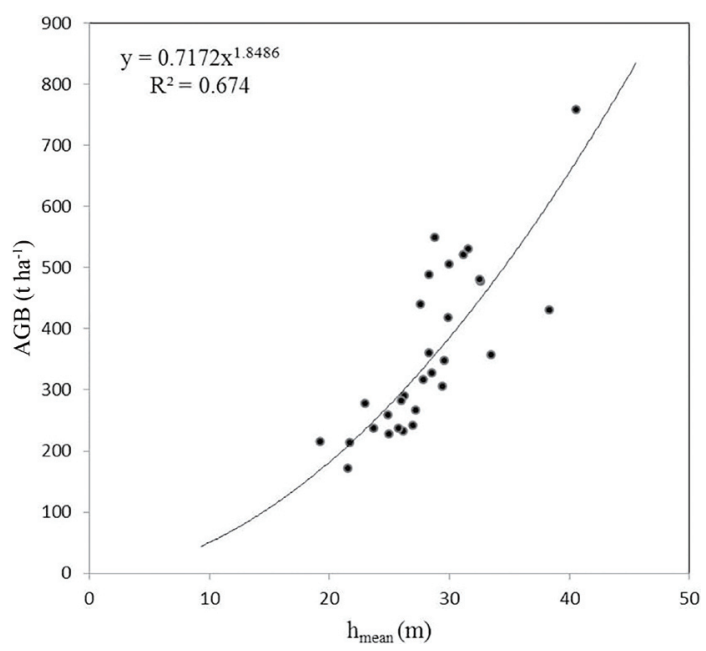

Fig. 5. Relationship between $h_{\text {mean }}$ derived from the LiDAR data and AGB fitted with a power regression model.

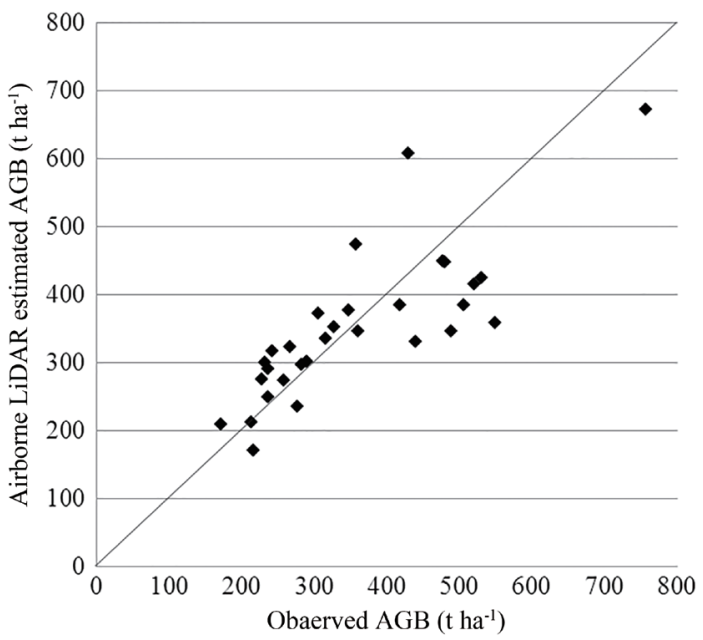

Fig. 6. Observed AGB ( $t$ ha $\left.^{-1}\right)$ versus LiDAR estimated AGB $\left(\mathrm{t} \mathrm{ha}^{-1}\right)$. 
was logged selectively 25 years ago and still shows clear impacts of the logging operation on both stand structure and AGB (Fig. 3). The DBH and height data for the plots had a right skew, with the mean $\mathrm{H}$ and $\mathrm{DBH}$ to the lower side of the data distribution (Table 2). The site had very few trees greater than $50 \mathrm{~m}$, with most of the AGB contributed by the 20 - 50 m height class. Since the AGB was calculated with both $\mathrm{H}$ and $\mathrm{DBH}$ in the Yamakura's allometric equation, the mean AGB also skewed to the right side of the data distribution. While our estimated mean AGB of $358.58 \mathrm{t} \mathrm{ha}^{-1}$ (Table 2), is low compared to AGB estimate of $506.37 \mathrm{t} \mathrm{ha}^{-1}$ for a primary mixed dipterocarp forest (Tangki and Chappell 2008), it is, however, comparable to estimate obtained for logged-over mixed dipterocarp forests. Langner et al. (2012) reported a mean AGB of $335.8 \mathrm{t} \mathrm{ha}^{-1}$ for the loggedover forests of the Deramakot Forest Reserve.

We found a substantial variation in AGB within the sample of 30 plots (Figs. 3 and 4), suggesting that the past disturbances were not uniform and caused the regenerating forest to become highly heterogeneous (Brown and Lugo 1992). The AGB of the heterogeneous logged-over forest in the study site could be estimated from the mean canopy height (Fig. 5). Selective logging created canopy gaps (Johns 1988) allowing laser-pulse penetration through the forest canopy. Heterogeneous forest structure means differences in vertical layering (Asner et al. 2009). Loss of emergent and upper canopy trees enables the lower canopy trees to receive more laser pulses thus allowing for a better assessment of the lower vertical layer forest structure. By taking the mean of all laser pulse first returns, the mean canopy height considered trees in all sizes in the vertical layers, and thus accurately characterized the three dimensional tree distribution of the logged-over forest.

Mean height metric from LiDAR data has widely been used to develop the AGB or carbon estimation models: lowland rainforest in Central Kalimantan (Jubanski et al. 2013), rainforest in Panama, Peru, Madagascar, and Hawaii (Asner et al. 2012c), and tropical montane forest in Sabah, Borneo (Ioki et al. 2014). Although the model's coefficient of determination was not very high $\left(R^{2}=0.67\right)$, the single-variable model had an RMSE of $22.31 \%$ of the mean AGB, which is lower than the RMSE of the single-variable model using mean canopy height (28\% of the mean AGB) and multiplevariable model (26\% of the mean AGB) (Ioki et al. 2014). Overall the estimated AGB corresponded well with the observed AGB (Fig. 6). Only a few plots had considerable over and under-estimation issues. Further examination of the plots with AGB over-estimation suggest that this was due to the presence of a few big trees in a relatively low density stand. As most of the LiDAR pulses were reflected by the few big trees, the $h_{\text {mean }}$ values became relatively high, thus tending to over-estimate the AGB. On the other hand, AGB under-estimation occurred in a few plots with $\mathrm{h}_{\text {mean }}$ of more than $25 \mathrm{~m}$ but less than $30 \mathrm{~m}$. These areas were heavily logged 25 years ago and provided a lot of gaps for regeneration. These areas are now constituted by mostly medium-size trees that are summed to a substantial amount of AGB. Nevertheless, these plots were within the RMSE with the exception of one plot. This plot had $70 \%$ more trees than an average plots with similar mean $\mathrm{H}$ and $\mathrm{DBH}$, leading to a higher observed AGB than was derived from the LiDAR data.

\section{CONCLUSION}

This study examined the use of airborne LiDAR to estimate AGB in a logged-over forest in Sabah. Among the LiDAR variables, mean canopy height was best correlated with AGB in the logged-over forest. The AGB estimation model using mean canopy height had the lowest RMSE, suggesting it yields the most accurate AGB estimates and can be used as a reliable approach to estimate carbon stocks for REDD+. While the deployment of an airborne LiDAR sensor is relatively expensive, it greatly reduces the number of field plots required to accurately estimate the AGB of a highly heterogeneous logged-over forest. We suggest that LiDAR based estimates will be more time and cost effective, and provide a more realistic Measurement, Reporting, and Verification (MRV) system for REDD+. As most of the permanent forest estates in Sabah consist of logged-over forests, further studies are recommended to see if the mean canopy height is the universal predictor for AGB for other logged-over lowland rainforest sites in Sabah and to also investigate whether these findings can be applied to estimate carbon stocks in the remaining primary lowland rainforests.

Acknowledgements This project was funded by the Ministry of Education, Malaysia (Fundamental Research Grant Scheme-Transdisciplinary: FTD0001-STWN-1-2013). We sincerely thank the Sabah Forestry Department, Department of Survey and Mapping, Malaysia, Sabah Foundation and Sabah State Government for their permissions to perform this work, the Royal Society for the field support and the Universiti Malaysia Sabah for technical assistance.

\section{REFERENCES}

Asner, G. P., R. F. Hughes, T. A. Varga, D. E. Knapp, and T. Kennedy-Bowdoin, 2009: Environmental and biotic controls over aboveground biomass throughout a tropical rain forest. Ecosystems, 12, 261-278, doi: 10.1007/ s10021-008-9221-5. [Link]

Asner, G. P., J. K. Clark, J. Mascaro, R. Vaudry, K. D. Chadwick, G. Vieilledent, M. Rasamoelina, A. Balaji, T. Kennedy-Bowdoin, L. Maatoug, M. S. Colgan, and D. E. Knapp, 2012a: Human and environmental controls over aboveground carbon storage in Madagascar. Carbon Bal. Manag., 7, doi: 10.1186/1750-0680-7-2. [Link] 
Asner, G. P., J. K. Clark, J. Mascaro, G. A. G. García, K. D. Chadwick, D. A. N. Encinales, G. Paez-Acosta, E. C. Montenegro, T. Kennedy-Bowdoin, Á. Duque, A. Balaji, P. von Hildebrand, L. Maatoug, J. F. P. Bernal, A. P. Y. Quintero, D. E. Knapp, M. C. G. Dávila, J. Jacobson, and M. F. Ordóñez, 2012b: High-resolution mapping of forest carbon stocks in the Colombian Amazon. Biogeosciences, 9, 2683-2696, doi: 10.5194/ bg-9-2683-2012. [Link]

Asner, G. P., J. Mascaro, H. C. Muller-Landau, G. Vieilledent, R. Vaudry, M. Rasamoelina, J. S. Hall, and M. van Breugel, 2012c: A universal airborne LiDAR approach for tropical forest carbon mapping. Oecologia, 168, 1147-1160, doi: 10.1007/s00442-011-2165-z. [Link]

Axelsson, P., 2000: DEM generation from laser scanner data using adaptive tin models. Int. Arch. Photogram. Rem. Sens., XXXIII, 110-117.

Brown, S., 1997: Estimating biomass and biomass change of tropical forests: A primer. FAO Forestry Paper 134, FAO - Food and Agriculture Organization of the United Nations, Rome. Available at http://www.fao. org/docrep/w4095e/w4095e00.htm.

Brown, S. and A. E. Lugo, 1992: Aboveground biomass estimates for tropical moist forests of the Brazilian Amazon. Interciencia, 17, 8-18.

Chave, J., C. Andalo, S. Brown, M. A. Cairns, J. Q. Chambers, D. Eamus, H. Fölster, F. Fromard, N. Higuchi, T. Kira, J. P. Lescure, B. W. Nelson, H. Ogawa, H. Puig, B. Riéra, and T. Yamakura, 2005: Tree allometry and improved estimation of carbon stocks and balance in tropical forests. Oecologia, 145, 87-99, doi: 10.1007/ s00442-005-0100-x. [Link]

Clark, M. L., D. A. Roberts, J. J. Ewel, and D. B. Clark, 2011: Estimation of tropical rain forest aboveground biomass with small-footprint lidar and hyperspectral sensors. Remote Sens. Environ., 115, 2931-2942, doi: 10.1016/j.rse.2010.08.029. [Link]

Drake, J. B., R. O. Dubayah, D. B. Clark, R. G. Knox, J. B. Blair, M. A. Hofton, R. L. Chazdon, J. F. Weishampel, and S. D. Prince, 2002: Estimation of tropical forest structural characteristics using large-footprint lidar. Remote Sens. Environ., 79, 305-319, doi: 10.1016/ S0034-4257(01)00281-4. [Link]

FAO, 1987: Development of forest sector planning. Technical Repot, FO:DP/MAL/85/004, FAO, Rome, Italy.

Gibbs, H. K., S. Brown, J. O. Niles, and J. A. Foley, 2007: Monitoring and estimating tropical forest carbon stocks: Making REDD a reality. Environ. Res. Lett., 2, 1-13, doi: 10.1088/1748-9326/2/4/045023. [Link]

Houghton, R. A., 2005: Aboveground forest biomass and the global carbon balance. Global Change Biol., 11, 945958, doi: 10.1111/j.1365-2486.2005.00955.x. [Link]

Hutton, J., A. Ip, T. Bourke, B. Scherzinger, N. Gopaul, P.
Canter, I. Oveland, and L. Blankenberg, 2008: Tight integration of GNSS post-processed virtual reference station with inertial data for increased accuracy and productivity of airborne mapping. The $21^{\text {st }}$ ISPRS Congress Technical Commission V, Beijing, China. Available at http://www.applanix.com/media/downloads/articles papers/integration $\% 20$ of $\% 20$ gnss $\% 20$ pp\%20virtual\%20reference $\% 20$ station $\% 20$ with $\% 20$ inertial\%20data.pdf.

Ioki, K., S. Tsuyuki, Y. Hirata, M. H. Phua, W. V. C. Wong, Z. Y. Ling, H. Saito, and G. Takao, 2014: Estimating above-ground biomass of tropical rainforest of different degradation levels in Northern Borneo using airborne LiDAR. For. Ecol. Manage., 328, 335-341, doi: 10.1016/j.foreco.2014.06.003. [Link]

Johns, A. D., 1988: Effects of "selective" timber extraction on rain forest structure and composition and some consequences for frugivores and folivores. Biotropica, 20, 31-37, doi: 10.2307/2388423. [Link]

Jubanski, J., U. Ballhorn, K. Kronseder, J. Franke, and F. Siegert, 2013: Detection of large above-ground biomass variability in lowland forest ecosystems by airborne LiDAR. Biogeosciences, 10, 3917-3930, doi: 10.5194/bg-10-3917-2013. [Link]

Kronseder, K., U. Ballhorn, V. Böhm, and F. Siegert, 2012: Above ground biomass estimation across forest types at different degradation levels in Central Kalimantan using LiDAR data. Int. J. Appl. Earth Observation Geoinformation, 18, 37-48, doi: 10.1016/j.jag.2012.01.010. [Link]

Langner, A., J. Miettinen, and F. Siegert, 2007: Land cover change 2002-2005 in Borneo and the role of fire derived from MODIS imagery. Global Change Biol., 13, 2329-2340, doi: 10.1111/j.1365-2486.2007.01442.x. [Link]

Langner, A., H. Samejima, R. C. Ong, J. Titin, and K. Kitayama, 2012: Integration of carbon conservation into sustainable forest management using high resolution satellite imagery: A case study in Sabah, Malaysian Borneo. Int. J. Appl. Earth Observation Geoinformation, 18, 305-312, doi: 10.1016/j.jag.2012.02.006. [Link]

Lefsky, M. A., W. B. Cohen, S. A. Acker, G. G. Parker, T. A. Spies, and D. Harding, 1999: Lidar remote sensing of the canopy structure and biophysical properties of Douglas-fir western hemlock forests. Remote Sens. Environ., 70, 339-361, doi: 10.1016/S00344257(99)00052-8. [Link]

Lefsky, M. A., W. B. Cohen, D. J. Harding, G. G. Parker, S. A. Acker, and S. T. Gower, 2002: LiDAR remote sensing of above-ground biomass in three biomes. Glob. Ecol. Biogeogr., 11, 393-399, doi: 10.1046/j.1466822x.2002.00303.x. [Link]

Lu, D., 2005: Aboveground biomass estimation using 
Landsat TM data in the Brazilian Amazon. Int. J. Remote Sens., 26, 2509-2525, doi: 10.1080/ 01431160500142145. [Link]

Lu, D., 2006: The potential and challenge of remote sensing-based biomass estimation. Int. J. Remote Sens., 27, 1297-1328, doi: 10.1080/01431160500486732. [Link]

Magnussen, S. and P. Boudewyn, 1998: Derivations of stand heights from airborne laser scanner data with canopybased quantile estimators. Can. J. For. Res., 28, 10161031, doi: 10.1139/x98-078. [Link]

McMorrow, J. and M. A. Talip, 2001: Decline of forest area in Sabah, Malaysia: Relationship to state policies, land code and land capability. Global Environ. Change, 11, 217-230, doi: 10.1016/S0959-3780(00)00059-5. [Link]

Newbery, D. M.,E.J.F.Campbell, Y.F.Lee, C. E.Ridsdale, and M. J. Still, 1992: Primary lowland dipterocarp forest at Danum Valley, Sabah, Malaysia: Structure, relative abundance and family composition. Phil. Trans. Biol. Sci., 335, 341-356, doi: 10.1098/rstb.1992.0026. [Link]

Osman, R., M. H. Phua, Z. Y. Ling, and K. U. Kamlun, 2012: Monitoring of deforestation rate and trend in Sabah between 1990 and 2008 using multitemporal Landsat data. J. Forest Sci., 28, 144-151, doi: 10.7747/ JFS.2012.28.3.144. [Link]

Palace, M., M. Keller, G. P. Asner, S. Hagen, and B. Braswell, 2008: Amazon forest structure from IKONOS satellite data and the automated characterization of forest canopy properties. Biotropica, 40, 141-150, doi: 10.1111/j.1744-7429.2007.00353.x. [Link]

Patenaude, G., R. A. Hill, R. Milne, D. L. A. Gaveau, B. B. J. Briggs, and T. P. Dawson, 2004: Quantifying forest above ground carbon content using LiDAR remote sensing. Remote Sens. Environ., 93, 368-380, doi: 10.1016/j.rse.2004.07.016. [Link]

Phua, M. H. and H. Saito, 2003: Estimation of biomass of a mountainous tropical forest using Landsat TM data. Can. J. Rem. Sens., 29, 429-440, doi: 10.5589/m03005. [Link]

Phua, M. H., Z. Y. Ling, W. Wong, A. Korom, B. Ahmad, N. A. Besar, S. Tsuyuki, K. Ioki, K. Hoshimoto, Y. Hirata, H. Saito, and G. Takao, 2014: Estimation of above-ground biomass of a tropical forest in Northern Borneo using high-resolution satellite image. J. Forest Environ. Sci., 30, 233-242, doi: 10.7747/ JFS.2014.30.2.233. [Link]

Ross, M. L., 2001: Timber Booms and Rent Seeking in Southeast Asia, Cambridge University Press, 237 pp.

Saatchi, S., K. Halligan, D. G. Despain, and R. L. Crabtree, 2007: Estimation of forest fuel load from radar remote sensing. IEEE Trans. Geosci. Remote Sensing, 45, 1726-1740, doi: 10.1109/TGRS.2006.887002. [Link]

Tangki, H. and N. A. Chappell, 2008: Biomass variation across selectively logged forest within a $225-\mathrm{km}^{2}$ region of Borneo and its prediction by Landsat TM. For. Ecol. Manage., 256, 1960-1970, doi: 10.1016/j. foreco.2008.07.018. [Link]

UNFCCC (United Nations Framework Convention on Climate Change), 2009: Reducing emissions from deforestation in developing countries: Approaches to stimulate action. Subsidiary Body for Scientific and Technological Advice, Thirty-first session, Copenhagen, 8-12 December 2009. Available at http://unfccc. int/resource/docs/2009/sbsta/eng/119a01.pdf.

Wulder, M. A., J. C. White, R. F. Nelson, E. Næsset, H. O. Ørka, N. C. Coops, T. Hilker, C. W. Bater, and T. Gobakken, 2012: LiDAR sampling for large-area forest characterization: A review. Remote Sens. Environ., 121, 196-209, doi: 10.1016/j.rse.2012.02.001. [Link]

Yamakura, T., A. Hagihara, S. Sukardjo, and H. Ogawa, 1986: Aboveground biomass of tropical rain forest stands in Indonesian Borneo. Vegetatio, 68, 71-82, doi: 10.1007/BF00045057. [Link] 